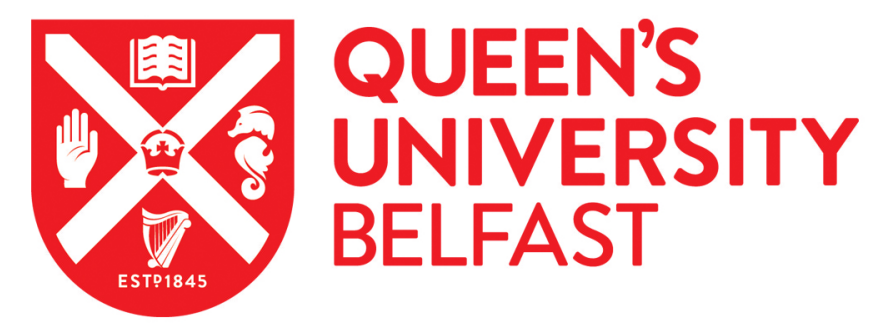

\title{
Microcosm studies on anaerobic phosphate flux and mineralization of lake sediment organic carbon
}

Song, J., Luo, Y. M., Zhao, Q. G., \& Christie, P. (2004). Microcosm studies on anaerobic phosphate flux and
mineralization of lake sediment organic carbon. Journal of Environmental Quality, 33(6), 2353-2356.

Published in:

Journal of Environmental Quality

Queen's University Belfast - Research Portal:

Link to publication record in Queen's University Belfast Research Portal

\section{General rights}

Copyright for the publications made accessible via the Queen's University Belfast Research Portal is retained by the author(s) and / or other copyright owners and it is a condition of accessing these publications that users recognise and abide by the legal requirements associated with these rights.

Take down policy

The Research Portal is Queen's institutional repository that provides access to Queen's research output. Every effort has been made to ensure that content in the Research Portal does not infringe any person's rights, or applicable UK laws. If you discover content in the Research Portal that you believe breaches copyright or violates any law, please contact openaccess@qub.ac.uk. 


\title{
Wetlands and Aquatic Processes
}

\section{Microcosm Studies on Anaerobic Phosphate Flux and Mineralization of Lake Sediment Organic Carbon}

\author{
Jing Song, Yongming Luo,* Qiguo Zhao, and Peter Christie
}

\begin{abstract}
Lake sediment has long been recognized as an important source of nutrients such as phosphorus. To gain a better understanding of phosphorus flux at the sediment-water interface, it is crucial to investigate the sediment porewater. There is also growing concern and interest in identifying whether organic-rich sediment is an important source of greenhouse gases such as $\mathrm{CO}_{2}$ and $\mathrm{CH}_{4}$. In the present study, we took sediment samples from West Lake, a shallow hypereutrophic lake in Hangzhou, Zhejiang Province, China and incubated subsamples under anaerobic conditions at $25^{\circ} \mathrm{C}$ for $182 \mathrm{~d}$ using a specially designed microcosm that permits repeated extraction of sediment porewater and sampling of headspace gases. Anaerobic phosphate fluxes and mineralization of sediment organic carbon were measured. Average diffusive flux of soluble phosphorus was $0.81 \mathrm{mg} \mathrm{m}^{-2} \mathrm{~d}^{-1}$ during the initial $18 \mathrm{~d}$ of incubation. Decomposition of sediment organic $\mathrm{C}$ followed zero-order reaction kinetics and methane accounted for about $50 \%$ of the mineralization products. The results suggest that organic-rich sediments can be important sources of $P$ and methane under anaerobic conditions. Laboratory studies simulating field conditions and field studies are necessary to determine the contribution of sediment as a source of $P$ and greenhouse gases.
\end{abstract}

T HAS LONG BEEN ESTABLISHED that sediment can act as an internal source of nutrients $(\mathrm{C}, \mathrm{N}$, and $\mathrm{P})$ to eutrophic shallow waters, especially when external inputs have been eliminated. In other words, the quality of the overlying water may be governed to some extent by the underlying sediment (Moore et al., 1991). Release of dissolved nutrients to the overlying water takes place near the sediment-water interface. Complex biological, physical, and chemical processes such as mineralization of sediment organic C, diffusion, oxidation-reduction, and solubilization-precipitation are involved. It is also near the sediment-water interface where significant gradients of the key influencing factors of the nutrient release process exist. For instance, sediment porewater chemistry is usually very different from that of the overlying water with regard to $\mathrm{pH}$, redox potential (Eh), dissolved oxygen, temperature, and concentration of electron receptors. Dissolved nutrients from decomposition of organic matter will be released into sediment porewater before they are transported into the overlying

J. Song, Y. Luo, and Q. Zhao, Soil and Environment Bioremediation Research Center, State Key Laboratory of Soil and Sustainable Agriculture, Institute of Soil Science, Chinese Academy of Sciences, P.O. Box 821, Nanjing 210008, China. P. Christie, Agricultural and Environmental Science Department, Queen's University Belfast, Newforge Lane, Belfast BT9 5PX, UK. Received 29 Dec. 2003. *Corresponding author (ymluo@issas.ac.cn).

Published in J. Environ. Qual. 33:2353-2356 (2004).

(c) ASA, CSSA, SSSA

677 S. Segoe Rd., Madison, WI 53711 USA water via diffusion, sediment resuspension, bioturbation, and gas ebullition (Gale and Reddy, 1994; Moore et al., 1998; Reddy et al., 1996). A better understanding of sediment porewater chemistry will therefore not only help in understanding diffusion and mineralization processes but also lead to a better understanding of the potential role of sediment in aquatic ecosystems.

Song et al. (2000) recently reviewed porewater sampling techniques. Destructive methods such as pressure filtration and anaerobic centrifugation may have high temporal and spatial resolution but do not allow sequential extraction. On the other hand, in situ close-interval samplers first proposed by Hesslein (1976), and modifications such as the one proposed by Ugo et al. (1999), have high spatial resolution but poor temporal resolution as they normally require several days or longer to reach equilibrium with the sediment porewater.

In an attempt to introduce sequential sediment porewater sampling with high temporal and spatial resolution in laboratory studies, we designed a microcosm (Chinese Utility Model Patent no. ZL 012 37794.5) that incorporates a small soil moisture sampler (Rhizon SMS; Rhizosphere Research Products, Wageningen, the Netherlands) to enable sequential extraction of sediment porewater. A previous study on ammonium flux showed that the Rhizon SMS sampler is a convenient device for use in microcosm experiments and permits repeated sampling with minimal disturbance of the experimental system. Using the patented microcosm, we found that diffusion was the dominant process in the initial fast phase of $\mathrm{NH}_{4}^{+}$release from sediment (Song et al., 2003). The objectives of the present study were to further test the microcosm device for studies on anaerobic phosphorus flux and mineralization of sediment organic carbon.

\section{MATERIALS AND METHODS}

\section{Sediment and Water Sampling}

Bulk sediments were collected from the surface layer $(0-30 \mathrm{~cm})$ near the center of West Lake, a shallow, hypereutrophic urban lake in Hangzhou city, Zhejiang Province, East China. Subsurface water samples were also collected from the same location.

\section{Experimental Setup}

A schematic diagram of the microcosm used in this study is shown in Fig. 1. Each cylindrical polythene vessel was $20 \mathrm{~cm}$ in diameter and $11 \mathrm{~cm}$ tall. Electrode probes for measurement

Abbreviations: DOC, dissolved organic carbon; Eh, redox potential; SMS, soil moisture sampler. 
$\mathrm{pH}$, ORP electrodes, and thermometer

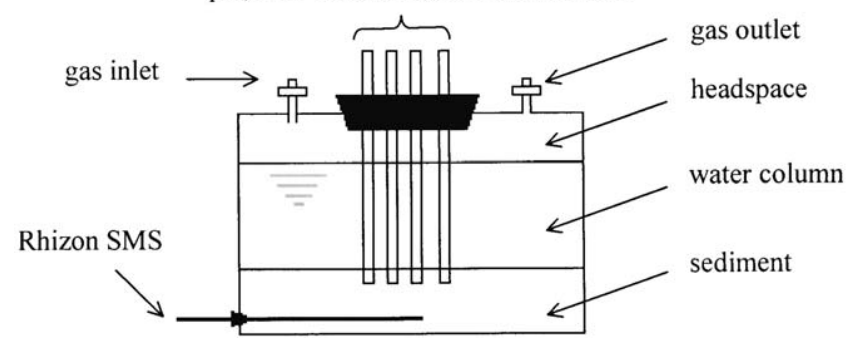

Fig. 1. Schematic diagram of the microcosm used in the laboratory simulation study. ORP, oxidation-reduction potential; SMS, soil moisture sampler.

of $\mathrm{pH}$ and oxidation-reduction potential (ORP) were inserted into the sediment to monitor dynamic changes in $\mathrm{pH}$ and $\mathrm{Eh}$ of the surface sediment. A small hole was drilled on the sidewall $0.5 \mathrm{~cm}$ above the base of the vessel through which a Rhizon SMS was inserted into the center of the microcosm through a rubber stopper. More detailed descriptions of the Rhizon SMS and the microcosm have been given by Wu and Luo (1999) and Song et al. (2003), respectively.

\section{Batch Incubation Experiment}

A batch incubation experiment was performed using four replicate sediment samples. Selected physical chemical properties of the sediment are shown in Table 1 . Thoroughly homogenized wet sediment ( $1675 \mathrm{~g}$, equivalent to $201 \mathrm{~g}$ on a dry matter basis) was placed in a microcosm to give a 5-cm-deep layer of sediment. Filtered West Lake water $(1250 \mathrm{~mL})$ was then added carefully to minimize disturbance. The depth of overlying water was $4 \mathrm{~cm}$. A redox $(\mathrm{Pt})$ electrode, an $\mathrm{Ag}-\mathrm{AgCl}$ electrode, and a compound $\mathrm{pH}$ electrode were carefully positioned so that the sensors could be inserted about $1 \mathrm{~cm}$ into the sediment layer. After the top of the microcosm was sealed with silica gel, the headspace was replaced with $99.999 \%$ purity $\mathrm{N}_{2}$ by flushing through the gas inlet and outlet. The microcosm was then incubated in the dark at $25^{\circ} \mathrm{C}$ for $182 \mathrm{~d}$. The $\mathrm{pH}$ and Eh of the sediment were monitored regularly. On Days 0, 28, $39,53,63,78,91,104,127,147,167$, and 182 the headspace was sampled by piercing the polypropylene stopper on the top with a needle and analyzed for methane by gas chromatography (Model C3800; Varian Instruments, Palo Alto, CA). Then, $15 \mathrm{~mL}$ of porewater was extracted using a plastic syringe connected to the Rhizon SMS sampler. Porewater was analyzed for soluble phosphorus and dissolved organic carbon by a molybdenum blue colorimetric method and a TOC analyzer (Model 1020; OI Analytical, College Station, TX). After the headspace and porewater were sampled, the microcosm was uncovered to withdraw $75 \mathrm{~mL}$ of the overlying water. After filtration through a $0.45-\mu \mathrm{m}$-pore membrane filter, the water sample was analyzed for soluble phosphorus and dissolved organic carbon using the same methods as for porewater. The $90 \mathrm{~mL}$ of water removed was replenished with filtered fresh West Lake water. The headspace was again purged with $99.999 \%$ purity $\mathrm{N}_{2}$, sealed, and incubated in the dark at $25^{\circ} \mathrm{C}$

Table 1. Selected physicochemical properties of the sediment. $\dagger$

\begin{tabular}{lcccccc}
\hline Bulk density & Porosity & pH & Eh & TC & TN & TP \\
\hline $\mathrm{g} \mathrm{cm}^{-3}$ & & & $\mathrm{mV}$ & & $\%$ & \\
& 0.88 & 7.16 & -185 & 14.91 & 1.07 & $\mathbf{0 . 0 7 4}$ \\
\hline
\end{tabular}

$\dagger$ Bulk density, porosity, total carbon (TC), total nitrogen (TN), and total phosphorus (TP) were determined on homogenized bulk sediment, while pH and redox potential $(\mathrm{Eh})$ data are mean values of four replicates measured at the start of the incubation period. until the subsequent sampling time. The results presented in this paper are the mean values of four replicates.

\section{RESULTS AND DISCUSSION pH and Redox Potential Dynamics of the Surface Sediment}

Sediment pH decreased from 7.16 to 6.87 over the first $10 \mathrm{~d}$ of incubation. From Days 10 to 109 , sediment $\mathrm{pH}$ was almost stable at around $6.86 \pm 0.02$. Thereafter, the $\mathrm{pH}$ began to drop and finally stabilized at $6.79 \pm$ 0.02 (Fig. 2). Sediment Eh dropped sharply from -185 to $-447 \mathrm{mV}$ over the initial $8 \mathrm{~d}$ and then returned to $-376 \mathrm{mV}$ on Day 31. Thereafter, sediment Eh decreased slowly to $-420 \mathrm{mV}$ (Fig. 2).

The sediment Eh and $\mathrm{pH}$ dynamics indicate that the sediment was under nearly neutral and highly reduced conditions throughout the laboratory incubation. According to $\mathrm{pE}-\mathrm{pH}$ charts (where $\mathrm{pE}$ is the negative logarithm of the electron activity) of Fe and $\mathrm{C}$ (not shown), $\mathrm{Fe}^{2+}$ and $\mathrm{CH}_{4}$ would be expected to be the dominant species present.

\section{Soluble Phosphorus Flux}

Under anaerobic conditions, soluble phosphorus concentration in the water column increased sharply over the first $18 \mathrm{~d}$ and continued to increase almost linearly at a slower rate until Day 127. Thereafter, soluble phosphorus concentration in the water column fluctuated at $1.50 \pm 0.04 \mathrm{mg} \mathrm{L}^{-1}$. Despite our expectation that soluble phosphorus concentration in sediment porewater might decrease during the initial $18 \mathrm{~d}$ due to diffusion into the water column as in the case of $\mathrm{NH}_{4}^{+}$in our previous study (Song et al., 2003), soluble phosphorus concentration in the sediment porewater was characterized by a substantial increase over the first $18 \mathrm{~d}$ followed by a much slower increase until the end of the incubation period (Fig. 3).

We supposed that the increase in soluble phosphorus concentration in the overlying water was the result of diffusion from the sediment. To test this assumption, diffusive flux of soluble phosphorus over the first $18 \mathrm{~d}$ was calculated from the porewater profiles using Fick's first law (Moore et al., 1991). The value for the ideal

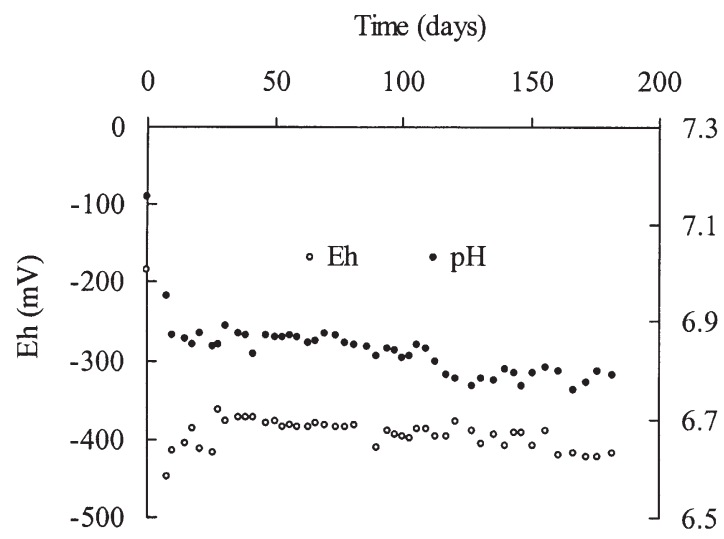

Fig. 2. Temporal changes in sediment redox potential (Eh) and pH during anaerobic incubation. 


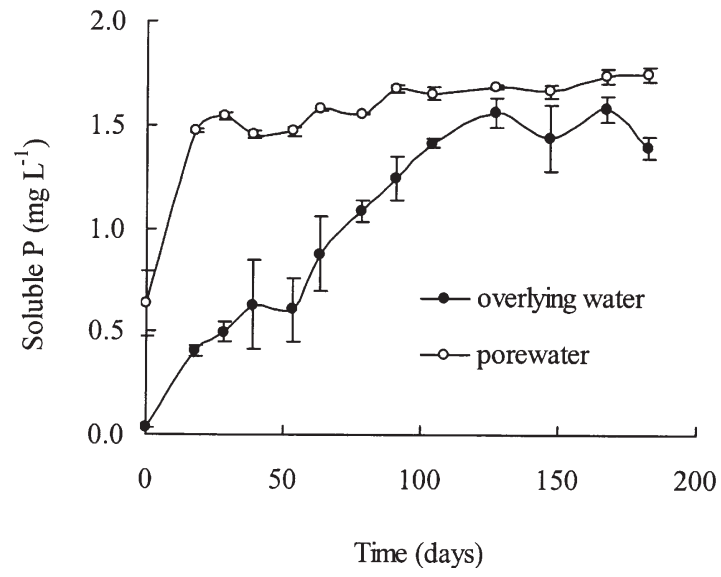

Fig. 3. Temporal changes in soluble phosphorus concentration in overlying water and sediment porewater. Bars indicate $\pm 1 \mathrm{SE}$ $(n=4)$.

diffusion coefficient of $\mathrm{PO}_{4}^{3-}$ in infinitely diluted solution, $D_{0}$, was set at 7.9 in units of $10^{-6} \mathrm{~cm}^{2} \mathrm{~s}^{-1}$ at $25^{\circ} \mathrm{C}$. Sediment porosity $(\phi)$, determined on the bulk sediment, was 0.88 . On the assumption that soluble phosphorus concentration gradient changed linearly between two consecutive sampling times, average soluble phosphorus flux during the first $18 \mathrm{~d}$ was calculated to be $0.81 \mathrm{mg} \mathrm{P} \mathrm{m}^{-2} \mathrm{~d}^{-1}$. This value is very close to the flux value calculated based on the changes in soluble phosphorus concentration in the overlying water $(0.88 \mathrm{mg}$ $\left.\mathrm{P} \mathrm{m}^{-2} \mathrm{~d}^{-1}\right)$. The good agreement between these two methods of calculation indicates that diffusion was the dominant process for soluble phosphorus release during the first $18 \mathrm{~d}$ of incubation. However, the phosphorus increment in the porewater over the first $18 \mathrm{~d}$ of incubation $(1.41 \mathrm{mg} \mathrm{P})$ was about 2.8 times that in the water column $(0.50 \mathrm{mg} \mathrm{P})$. A logical explanation for the increase in soluble phosphorus concentration in sediment porewater would be reduction of $\mathrm{Fe}$ (III) to $\mathrm{Fe}$ (II) due to the sharp decrease in Eh during the first $18 \mathrm{~d}$ as shown in Fig. 2 and subsequent solubilization of formerly Fe(III)-bound phosphorus. More phosphorus was solubilized to compensate for phosphorus reduction in the porewater due to diffusion into the water column. As a result of the decreasing concentration gradient after the initial $18 \mathrm{~d}$, the average soluble phosphorus flux from Days 18 to 127 was smaller. By measuring changes in soluble $\mathrm{P}$ concentration in the water column, average soluble phosphorus flux between Days 18 and 127 was calculated to be $0.56 \mathrm{mg} \mathrm{P} \mathrm{m}^{-2} \mathrm{~d}^{-1}$.

\section{Mineralization of Sediment Organic Matter}

Gale et al. (1992) defined total C mineralized under anoxic conditions as the sum of $\mathrm{CO}_{2}$ and $\mathrm{CH}_{4}$ plus the water-soluble and dissolved inorganic $\mathrm{C}$ produced during the incubation. Considering the unusually high concentration of organic carbon in the West Lake sediment as well as the highly reduced conditions in this study, for this experiment total $\mathrm{C}$ mineralized was defined as the sum of $\mathrm{CH}_{4}$ evolved plus dissolved organic carbon (DOC) produced during the incubation, including DOC

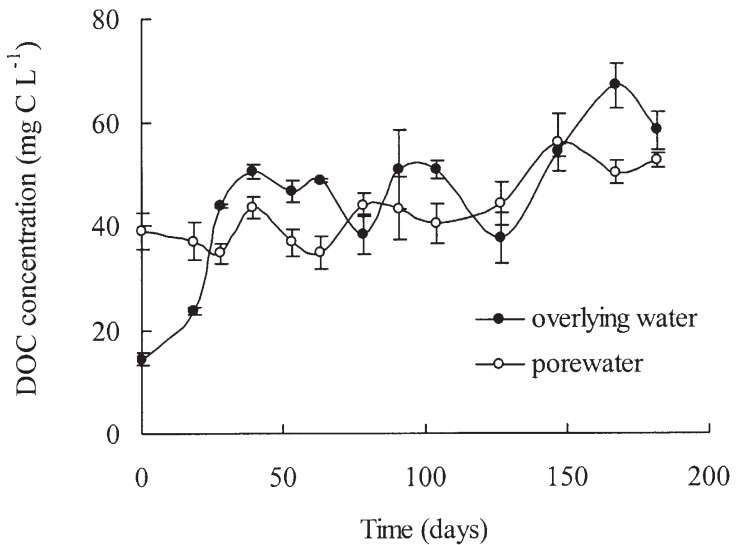

Fig. 4. Temporal changes in dissolved organic carbon (DOC) concentration in overlying water and sediment porewater. Bars indicate $\pm 1 \mathrm{SE}(n=4)$.

in the overlying water as well as DOC in the sediment porewater.

As shown in Fig. 4, DOC concentration was about two times higher in the sediment porewater $\left(39 \mathrm{mg} \mathrm{L}^{-1}\right)$ than in the water column $\left(14 \mathrm{mg} \mathrm{L}^{-1}\right)$ at the outset of the incubation. Over the first $18 \mathrm{~d}$, a decrease in DOC in porewater was coupled with an increase in DOC concentration in the overlying water. Thereafter, the difference in DOC concentration between porewater and overlying water was small. In some cases, the diffusion gradient was even toward the sediment. This indicates that diffusion of DOC from sediment to water column was important only at the initial stages as the DOC in porewater and overlying water rapidly reached equilibrium under the experimental conditions. Similarly, laboratory and field studies by Gale and Reddy (1994) also showed that diffusive flux of DOC from the sediment was minimal due to similar DOC concentrations in the overlying water and the sediment porewater.

Methane was detected in all headspace samples during incubation. Methane emission rate was found to be slow at the beginning and increased almost linearly between Days 18 and $182\left(r^{2}=0.94\right.$; data not shown $)$. Average $\mathrm{CH}_{4}$ emission rate was $10.6 \mathrm{mg} \mathrm{m}^{-2} \mathrm{~d}^{-1}$ for the initial $18 \mathrm{~d}$. In contrast, average and maximum $\mathrm{CH}_{4}$ emission rates from Days 18 to 182 were 28.4 and $39.6 \mathrm{mg} \mathrm{m}^{-2} \mathrm{~d}^{-1}$, respectively. Under the experimental conditions, cumulative $\mathrm{CH}_{4}$ flux reached $4.85 \mathrm{~g} \mathrm{~m}^{-2}$ over $182 \mathrm{~d}$. This value is comparable with the $\mathrm{CH}_{4}$ emission rate calculated by Cai et al. (2000) for most Chinese paddy fields during the rice-growing season. Methane emission showed zero-order kinetics. If methane was considered to be the sole end product, anaerobic decomposition of organic carbon showed zero-order kinetics, with a zero-order rate of $28.4 \mathrm{mg} \mathrm{m}^{-2} \mathrm{~d}^{-1}$. These values are within the same order of magnitude as those reported by Gale et al. (1992) for the slow phase of unconsolidated flocculent material. However, the question of whether or not $\mathrm{CH}_{4}$ can be released from West Lake sediment under field conditions requires further laboratory studies simulating field conditions in addition to actual field studies.

The percentage of total carbon mineralized is shown 


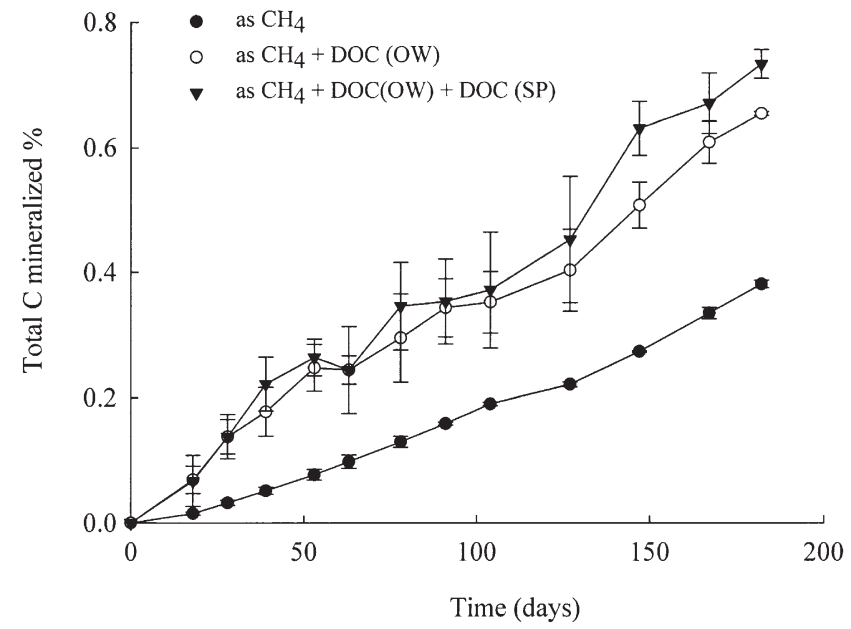

Fig. 5. Total carbon mineralized in West Lake sediment under anaerobic conditions expressed as $\mathrm{CH}_{4}, \mathrm{CH}_{4}+\mathrm{DOC}(\mathrm{OW})$, or $\mathrm{CH}_{4}+$ DOC $(O W)+$ DOC(SP), where DOC is dissolved organic carbon, $\mathrm{OW}$ is overlying water, and $\mathrm{SP}$ is sediment porewater. Bars indicate $\pm 1 \mathrm{SE}(n=4)$.

in Fig. 5. Methane accounted for about $50 \%$ of total end products of carbon decomposition. Even taking $\mathrm{CH}_{4}$ and DOC in the sediment porewater and DOC in the overlying water into consideration, total organic carbon mineralized in West Lake sediment was only $0.73 \%$ over $182 \mathrm{~d}$ under anaerobic conditions.

Decomposition of organic carbon is governed not only by the intrinsic nature of the sediment but also by environmental factors such as temperature and dissolved oxygen (Gale et al., 1992; Moore et al., 1992). In the present study, anaerobic decomposition of organic matter was rather slow and a multiphase decomposition pattern was not observed in this study. There are three possible reasons for this. First, surface sediments were homogenized before use to ensure repeatability of results from the four replicate subsamples and by so doing, the easily degradable flocculent fraction of the sediment was mixed with the less biodegradable subsurface fraction. Second, $\mathrm{CO}_{2}$ concentration in the headspace and dissolved $\mathrm{CO}_{2}$ and $\mathrm{CH}_{4}$ concentrations in the overlying water and sediment porewater were not measured in this study, and these may also have constituted products of organic matter decomposition (Gale et al., 1992). Third, the small pore size of the Rhizon SMS tubes (average $0.1 \mu \mathrm{m}$ ) may have filtered out large dissolved organic carbon molecules in the sediment porewater, leading to some underestimation of DOC concentration in the sediment porewater.

\section{CONCLUSIONS}

Compared with destructive methods for sediment porewater sampling such as centrifugation, Rhizon SMS samplers allow nondestructive, repeated, and convenient sampling of sediment porewater. By permitting dynamic monitoring of sediment properties (e.g., $\mathrm{pH}$ and Eh) as well as changes in aqueous and gaseous composition, the microcosm used in this study proved to be a useful tool to study nutrient flux across the sediment-water interface and mineralization of sediment organic matter under quiescent conditions. However, this microcosm design could be further improved for use in field studies. Under anaerobic conditions, organic-rich sediments can be important sources of phosphorus and $\mathrm{CH}_{4}$ emissions. Further laboratory studies simulating field conditions as well as field studies per se are needed to investigate the nutrient flux and mineralization rate of sediment organic carbon under field conditions.

\section{ACKNOWLEDGMENTS}

We thank the Chinese Academy of Sciences (Project KZCX3-SW-429) and State Key Basic Research and Development Program, MOST (Project 2002CB410810) for grantaided support. The study was also supported by the Joint Open Laboratory of Soil and Environment (JOLSE) at Institute of Soil Science, Chinese Academy of Sciences, Nanjing, China.

\section{REFERENCES}

Cai, Z.C., H. Tsuruta, and K. Minami. 2000. Methane emission from rice fields in China: Measurement and influencing factors. J. Geophys. Res. [Atmos.] 105:17231-17242.

Gale, P.M., and K.R. Reddy. 1994. Carbon flux between sediment and water column of a shallow, subtropical, hypereutrophic lake. J. Environ. Qual. 23:965-972.

Gale, P.M., K.R. Reddy, and D.A. Graetz. 1992. Mineralization of sediment organic matter under anoxic conditions. J. Environ. Qual. 21:394-400.

Hesslein, R.H. 1976. An in situ sampler for close interval pore water studies. Limnol. Oceanogr. 21:912-914.

Moore, P.A., K.R. Reddy, and M.M. Fisher. 1998. Phosphorus flux between sediment and overlying water in Lake Okeechobee, Florida: Spatial and temporal variations. J. Environ. Qual. 27:1428-1439.

Moore, P.A., K.R. Reddy, and D.A. Graetz. 1991. Phosphorus geochemistry in the sediment-water column of a hypereutrophic lake. J. Environ. Qual. 20:869-875.

Moore, P.A., K.R. Reddy, and D.A. Graetz. 1992. Nutrient transformations in sediment as influenced by oxygen supply. J. Environ. Qual. 21:387-393.

Reddy, K.R., M.M. Fisher, and D. Ivanoff. 1996. Resuspension and diffusive flux of nitrogen and phosphorus in a hypereutrophic lake. J. Environ. Qual. 25:363-371.

Song, J., Y.M. Luo, and Q.G. Zhao. 2000. Progress in study of soil solution sampling techniques. Turang (Nanjing) 32:102-106.

Song, J., Y.M. Luo, Q.G. Zhao, and P. Christie. 2003. Novel use of soil moisture samplers for studies on anaerobic ammonium fluxes across lake sediment-water interfaces. Chemosphere 50:711-715.

Ugo, P., A. Bertolin, and L.M. Moretto. 1999. Monitoring sulphur species and metal ions in salt-marsh pore-waters by using an insitu sampler. Int. J. Environ. Anal. Chem. 73:129-143.

Wu, L.H., and Y.M. Luo. 1999. Rhizon-soil moisture sampler-An introduction to an innovative in situ soil solution sampler. Turang (Nanjing) 31:54-56. 